\title{
Marketing Practices For Dairy Products From Small-Scale Farms, Case: Region Of Tiziouzou - Algeria
}

https://doi.org/10.21272/sec.5(4).149-165.2021.

Mehdi Bouchetara, ORCID ID: https://orcid.org/0000-0001-9826-8985

Dr., Assistant Professor, Higher National School of Management, Algeria

Lyna Mokhtari, ORCID ID: https://orcid.org/0000-0001-9166-327X

Master Student, Higher National School of Management, Algeria

Messaoud Lazreg, ORCID ID: https://orcid.org/0000-0002-4400-1238

$\mathrm{PhD}$, Researcher, Research Center in Applied Economics for Development

Messaoud Zerouti, ORCID ID: https://orcid.org/0000-0001-9802-5334

Dr., Assistant Professor, Higher National School of Management, Algeria

Sabrina Iraten, ORCID ID: https://orcid.org/0000-0002-0183-5769

Dr.,Assistant Professor, Higher National School of Management, Algeria

Lamia Elmokretar, ORCID ID: https://orcid.org/0000-0002-1207-4970

Dr., Assistant Professor, Higher National School of Management, Algeria

\begin{abstract}
The objective of our work is to identify the different marketing practices and to characterize the organizational constraints that hinder the productivity and profitability of small-scale livestock farms in the mountainous region of Fréha and Sidi-Naman, located in the region of Tizi-Ouzou, Algeria. Due to its high milk production potential, the targeted region was selected as a study area. The importance of our work lies in the determination of the key factors, which prevent small-scale milk producers from carrying out their livestock activities successfully. A quantitative questionnaire survey was conducted with 30 farmers. This study was complemented by interviews with livestock professionals. A documentary search of the literature and empirical studies was conducted, as well as site visits. The results show that there are several factors that impact on the normal course of productive activities of small-scale livestock farmers. The results show that there are several factors impacting on the normal production activities of small-scale farmers, such as: food and socio-cultural factors that are a constraint on milk production; distribution, which is strongly impacted by covid-19; lack of communication about products; and poorly organized marketing channels, especially in relation to goat farming, which accounts for $43 \%$ of our sample. We suggest that small breeders follow training courses on breeding methods and good practices, and improve hygiene and sterilization conditions on the farms, and strengthen the health control systems at the farm level. The contribution of the Algerian state for the regularization of the prices of animal products. To practice a good communication around the products processed by the small breeders to increase the marketing and sensitize the consumers to consume natural products. Exploit various other resources such as sheep milk by improving the dairy breeds of the region of Ouled Djellal. Orient goat farms towards intensive operations, and promote dairy breeds such as the Spanish Murciana and the French Saanen.
\end{abstract}

Keywords: marketing practices, small farmers, dairy production, organizational constraints.

JEL Classification: M21, M31, R30. 
Cite as: Bouchetara, M., Mokhtari, L., Lazreg, M., Zerouti, M., Iraten, S., Elmokretar, L. (2021). Marketing Practices For Dairy Products From Small-Scale Farms, Case: Region Of Tiziouzou - Algeria. SocioEconomic Challenges, 5(4), 149-165. https://doi.org/10.21272/sec.5(4).149-165.2021.
Received: 09.10 .2021
Accepted: 02.12 .2021
Published: 30.12 .2021

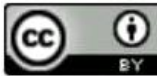

Copyright: (C) 2021 by the authors. Licensee Sumy State University, Ukraine. This article is an open access article distributed under the terms and conditions of the Creative Commons Attribution (CC BY) license (https://creativecommons.org/licenses/by/4.0/).

\section{Introduction}

Agriculture is experiencing increasing changes especially in the Mediterranean areas; agricultural and territorial activities play an important role in the lengthening of local and global affairs (Martine Napoleone, Jean-Pierre Boutonnet, 2016). In Algeria, especially in the mountainous regions, small-scale livestock farming contributes to food security, to the economic status of mountain households, and to their maintenance in poor and difficultto-access territories (Khelaf Saidani, 2019). However, certain changes in the environment of livestock farms, such as climatic disturbances, demographic growth, the influence of the market and especially the internationalization of trade, have affected small-scale livestock farmers in terms of production (Mouhous Azzeddine, 2015).

The growing number of consumers who are interested in improving their health condition is constantly increasing. However, understanding consumers' expectations for such products helps small-scale producers to transform their milk production into derivatives, and to design suitable marketing strategies to reach consumers desiring to improve their health. (Yilmaz-Ersan, Ozcan, \& Akpinar-Bayizit, 2020). The milk chain includes three main sales channels: industrial products, cheeses and other dairy specialties. (Sophie Reviron, 2018).

Resonance in terms of milk chain helps to improve the capacity of producers, in order to solve difficulties, make production decisions and exploit loopholes through the interventions of all key players in the chain (SOLTANI, 2017). Dairy production development policies should focus on strategies to improve productivity and profitability in mountainous areas (Mouhous, Djellal, Guermah, \& Kadi, 2020). Small-scale milk producers have become key players in all channels. (Barragan-ochoa, 2018) These small farms are based on the valorisation of local breeds of the country with low dairy potential. (Missouhou, 2020). In Algeria, the activity of dairy farming is neglected because of the most widespread strategies, diversification and pluriactivity. While there is a strong potential for the development of other sources of milk (goat, ewe, camel) that will help the growth of the dairy basin (Lazereg, Bellil, Djediane, \& Zaidi, 2020).

The growth of dairy production plays an important role in the economic development of the country (Mouhous \&Cherfaoui. LM, 2015). Indeed the production of milk is still low despite the implementation of strategies to support the production and collection of milk. (SRAIRI \& BAHRI, 2013). However, Algerian dairy farming still suffers from several flaws (Mouhous \& LM.Cherfaoui, 2015).

Our study will focus on their marketing practices with the aim of increasing and improving milk production in Algeria. Following the studies of (k.Dieng, 2014) on the socio-economic factors of its actors in the dairy sector and the various obstacles that impact the local milk value chain in Senegal. So that we can achieve our objectives, our research question is formulated as follows: What are the organizational constraints that impact the commercial practices of small-scale milk producers?

Several academic works have addressed this issue (k.Dieng, 2014), (Barragan-ochoa, 2017) and (A.Mouhous, et al., 2018). Our contribution will be to study the socio-economic variables, organizational constraints, profitability of farmers, and the brakes that influence the marketing practices of dairy products from small-scale farms. In order to answer this problem, we put forward two hypotheses:

H1: The socio-economic status of small-scale milk producers has a direct relationship with the productivity and 
profitability of farmers.

$\mathrm{H} 2$ : The irrationality of the actors and the lack of education have a negative impact on the production of smallscale farmers.

\section{Literature review}

\subsection{The contribution of the sectorial approach}

Inspired by industrial economics, the commodity chain approach helps analyze the growth of urban markets and incorporate farmers into the market economy (Soltani, 2017). Moreover, it is considered as an operational and strategic division of the economy, it refers to the set of production, transformation and distribution actors related to a product or a group of products, with the aim of satisfying consumption.

The value chain approach is a tool for analysis and development of strategic actions, which represents an instrument that directs the regional and national economic policy of a country. The objective of using the concept of value chain is to understand and analyze the strategy of firms using SWOT analysis, in order to define the strengths, weaknesses, opportunities and threats on the organizational, economic and commercial level. The article (Ludovic Trempel, 2013) indicates that the commodity chain is an economic concept that complements the notion of branch or sector in order to understand the dynamics of emergence, decline and configuration of its components. The perishable nature of agricultural products such as (Milk, Fruits, Vegetables, Meat) lead the work on the choices of actors to increase the management of quality and risk throughout the chain. The concept of commodity chain becomes an important tool for public decisions; it also helps to analyze the growth of urban food markets, based on the Walrasian paradigm and the development of experimental economics.

\subsection{The contribution of the territorial approach}

Agriculture is undergoing increasing changes especially in the Mediterranean areas; agricultural and territorial activities play an important role in the extension of local and global affairs According to (Martine.N, Boutonnet J.P, 2016). The interactions between the sectors/breeding systems and territories impact the development models and help to establish an analysis of the evolution of the dairy actions in a specific territory, the results of this reasoning demonstrate that the evolution of this sector is directly related to the growth of consumption. The existence of development models helps to respond to the increase in world food demand, the geographical concentration of urban demand and the sustainability of activities in the territories. The method used is to schematize the different interactions between marketing, types of products sold, breeding methods, territories as a system, there can be different types of systems, and each system has its own coherences and does not necessarily have the same attributes.

\subsection{Distribution of value in the dairy sector}

The distribution of the value created between actors in a sector has always been a challenge for researchers and public authorities in order to guarantee the resilience of vulnerable actors. In addition, the objective is to detect elements of analysis and identify actions to be taken to improve the return of value to agricultural producers. A documentary search of the scientific literature and empirical studies was carried out, mainly through interviews with experts and professionals in the sector, and possibly through site visits (Sophie Reviron, 2018).

The originality and quality of the ingredient is a key element in determining its value, if the batches are available in large quantities in this case the purchase is made in spot at the market price regardless of its value. It only takes a few quantities more or less to make the price go up or down overall market. The results of this paper show that the more producers and processors are able to differentiate their products and get the consumer to pay more, the higher the share of value perceived by retailers. The study focuses on the impact of governance structure on the return of value to producers.

\subsection{Socio-economic factor}

The article (k.Dieng, 2014) studies the different organizational constraints that impact the local milk value chain 
in Senegal, the authors focus on the socio-economic factor of its actors. The strong demographic growth of the country implies an increase in the local demand for dairy products. The authors therefore question the impact of the socio-economic profile of the actors on the dairy productivity; they therefore chose the Kaolack region thanks to its high productive potential of milk to conduct their study. The survey was conducted by administering questionnaires and interviews with professionals and stakeholders, the questions relate to the characteristics of gender, age and socio- professional activity, the analysis used in this study is the descriptive statistical method made using SPSS for the calculation of frequencies, means and standard deviations. The results led to understand the impact of several variables on production. the authors find that the intergenerational gaps are very high as well as the actors of the value chain, are characterized by a higher rate of illiteracy and not only depend on working on the dairy sector but they prefer to diversify their professional activities which negatively impact the development and innovation in the livestock sector and dairy production. The study shows that the development of the value chain in the milk sector in this region is very limited due to the mismanagement of actors, lack of education and professionalism.

\subsection{Diversification strategies on farms}

The article (Hochuli, Hochuli, \& Schmid, 2021) focuses on the strategic concepts of farm diversification and specialization in dairy production, the aim of the latter is to know which strategy to adapt to increase farmers' profitability. Many studies in the academic literature assume that diversification strategy and direct marketing of agricultural goods or services such as agritourism can absorb price volatility, but agritourism activities generate uncertain returns on investment due to general risks and lack of knowledge in tourism services operation management. Direct marketing from the farm involves different distribution channels, including farmers' markets in town, farm shops or mail order from farms. Farmers engage in direct marketing for a better income. Consumers are looking for security of supply and traceability of products.

According to the authors of this article, there are other factors that positively impact the strategy of direct marketing and agritourism as diversification strategies for successful farming. The geographical location of the dairy sectors and an important element in the strategic orientation towards specialization or diversification, given the different altitudes it is favorable to make production in the lowland regions than the mountainous and hilly regions, therefore the volumes of productions will be different and therefore the farm income and costs will be also different.

In conclusion, the study shows that farms using agritourism have a better result than farms practicing direct marketing and specialization. In addition, it is more profitable to adapt a service that responds to the demand and is different from the tourist enterprises, and the income objectives are achieved by the farms using agritourism.

\subsection{Socio-demographic factor and probiotic dairy products}

The article (Yilmaz-Ersan, Ozcan, \& Akpinar-Bayizit, 2020) discusses the growing number of consumers who are interested in improving their health status, which is why probiotic dairy products have become the fastest growing rational supply market.

The study is conducted with 314 participants in the city of Bursa, Turkey. The objective of the article is to analyze and evaluate the socio-demographic characteristics, health status and awareness of consumers regarding dairy products, in order to better understand consumer attitudes. Therefore, they ask for more information on how to lead a healthier life through their diet.

According to the scientific literature, probiotics are considered as functional food substances, i.e. microorganisms that are benign for human health. Many researchers have focused on the health benefits of consumption, consumer perceptions and attitudes, and factors affecting purchase intentions. These studies have shown that the factors that impact the acceptability of probiotic products are the intrinsic and extrinsic food functions (appearance, taste, pleasure, safety, familiarity), as well as factors related to the consumers (lifestyle, socio-demographic and psychological characteristics, perceived values), and also factors related to the commercial environment. 


\subsection{Economic performance of cattle farming}

The article (Mouhous, Djellal, Guermah, \& Kadi, 2020) discusses the exploration of technical aspects and economic performance of cattle breeding in mountainous areas. The objective of this study is to identify the constraints, and the different technical potentialities of cattle farms. The study is carried out with 100 dairy farmers during 7 months, by administering questionnaires. The method used in this paper is descriptive analysis (frequency and standard deviations), with the aim of determining the similarities that characterize the farms and the identification of differentiating factors. The study was carried out by analyzing a K-Menascluster ING on a set of variables related to the agricultural area, the number of cows, the annual work unit and the possession of a tractor. The analysis of the results of this study are used to compare the management, production and economic performance of cattle farms.

For the estimation of the economic performance of dairy production, some parameters were calculated as cost variables: veterinary products feed and labor. The results show that all the respondents are engaged in beef farming as their main activity. Less than $5 \%$ have a secondary activity, the average age of the farmers is 35 years, and the average productivity of the cows is around $10.5 \mathrm{KG} / \mathrm{D}$ with two milking's/day, the milk consumption per day represents $2.8 \%$ of the milk production. Production subsidies represent $58 \%$ of the average income of farmers, which proves the low return of the dairy cattle farm. In conclusion, dairy production development policies should focus on strategies to improve productivity and profitability in mountain areas.

\subsection{The impact of cyclical crises on the local dairy industry}

The authors (Lazereg, Bellil, Djediane, \& Zaidi, 2020) demonstrate the impact of covid-19 on the dairy sector, focusing on changes in trade policies that lead to decreased exports and increased imports. These actions lead to higher food prices, lower household incomes and increased hunger in the world. Algeria has taken corrective measures for strategic quotas that are acceptable at present, but that may generate future risks due to price volatility on the world market. The authors of the article propose a reflection, for the milk sector concerning the changes of the state subsidies of prices, towards a policy of targeting. The objective is to push the actors to create integrated production poles, segmentation according to the size of the farms, and the organization of the marketing circuits, so that the stockbreeders create values in the circumstances with a high degree of risk.

The global covid-19 pandemic has had a negative impact on the world economy, the transition from a health crisis to an economic crisis has created challenges for the key sectors that contribute to food security, indeed the dairy sector has been affected, and thus observations reveal a strong disruption in livestock value chains. The milk sector in Algeria is very independent of world input markets, and this dependence has increased with the arrival of the COVID-19 pandemic

Dairy production in Algeria has several structural flaws that prevent the normal development of the production process, and climatic conditions are a limiting factor in the evolution of this sector, especially cheese production, which is the main obstacle. The activity of dairy farming is being neglected because of the most widespread strategies, diversification and pluriactivity. There is another potential for the development of other sources of milk (goat, ewe, camel) which will help the growth of the dairy basin, the public authorities must popularize the organization of the breeders, in association with the professionals in order to find adequate solutions to the constraints, which prevent the normal functioning of this sector.

\subsection{Strategies for dealing with covid-19}

The article (Missouhou, 2020) analyses the consequences and effects of covid-19 on the milk and dairy products value chain and the strategies applied by the stakeholders. Production was negatively impacted by the pandemic with a 33\% drop, the production and processing segment experienced job losses in the form of job abandonment or layoffs that were reported. Today, the milk industry and trade are experiencing strong growth, driven by a very high population increase. The demand for milk and its derivatives is constantly increasing. The author's show that the exploitation of the dairy sectors is extensive, located in rural areas. In addition, other semiintensive exploitation in peri-urban areas. These farms are based on the valorization of local breeds of the country with low dairy potential. The general objective of the study is to analyze the effects of covid-19 on the 
value chain of milk and dairy products, as well as the strategies developed by socio-professional and private actors to help increase the value of the production chain.

The method used in the study is a bibliographic approach, and the mapping of actors. Following an online data collection, the collection tools were distributed to producers and milk processors. The data collected was analyzed using SPSS software. The results show that there is an imbalance in Senegal's trade balance and disruptions in production due to several factors. The increase in imports of milk powder and products increased by $17 \%$, which could be interpreted as market anticipation of the risk of milk shortages. The corrective measures desired by the stakeholders are to strengthen the dairy cooperatives, facilitate the marketing of milk and derived products, and better protection for raw milk in relation to imported powder.

The negative impact of COVID-19 on the milk value chain and dairy products, resulting in financial and economic losses. Such an approach will allow the milk value chain in Senegal to evolve constantly during a period of crisis.

\subsection{Dairy policies in Algeria}

The paper (Makhlouf, Montaigne, \& Tessa, 2020) analyzes the effectiveness of the new dairy policy, as well as the dairy balance sheet and the constraints it faces. Based on the analysis of the evolution of the four performance indicators. Milk and dairy products occupy an important place on the Algerian market, holding the second place among imported food products. The policies implemented to reduce the dependence on marketing measures, and price administration measures. The main objective of this study is to clarify the new policy adapted for the milk sector in Algeria to the instability of the world market, by relying on the development of local production, by keeping a social policy by the support of the prices, and by supporting the improvement of the products with strong benefit. Despite the reduction in the export of milk powder, the industries are still dependent on the world market. Processors in the private sector are looking for profit margins in other dairy products at free prices, rather than in milk production.

If the consumer gets a variety of products at low prices, the economic performance of the milk sector will be impacted by the informal sector.

The consumer price of milk is almost unattainable over a long period, and will not be consistent with production costs nor with the evolution of the standard of living of most of the population, as well as the strong differentiation of production costs that is difficult to take into account. Even if the state aid for the milk sector is judged to be rather modest compared to other food products. All the choices made for the dairy policy represent a challenge to be ensured.

\section{Presentation of the study area}

The willaya of Tizi-Ouzou is located $100 \mathrm{~km}$ east of Algiers. It is characterized by an agricultural potential of 29.5793 hectares with $80 \%$ of land on slopes. The climate of the department is Mediterranean, defined by two seasons, a wet and cold winter and a dry and hot summer. The population is strongly rural with a percentage of $63 \%$ of inhabitants distributed on 1400 villages. The wilaya has a high demographic condensation 441 inhabitants per square km according to the Directorate of Planning and Land Development in 2012.

Our study area is Fréha which represents $7 \%$ of the surface of the department of Tizi-Ouzou. It is known by its high milk production since 2000, cattle breeding has taken over to become an income generating activity, especially for small farmers (H Si-Tayeb, 2015). 


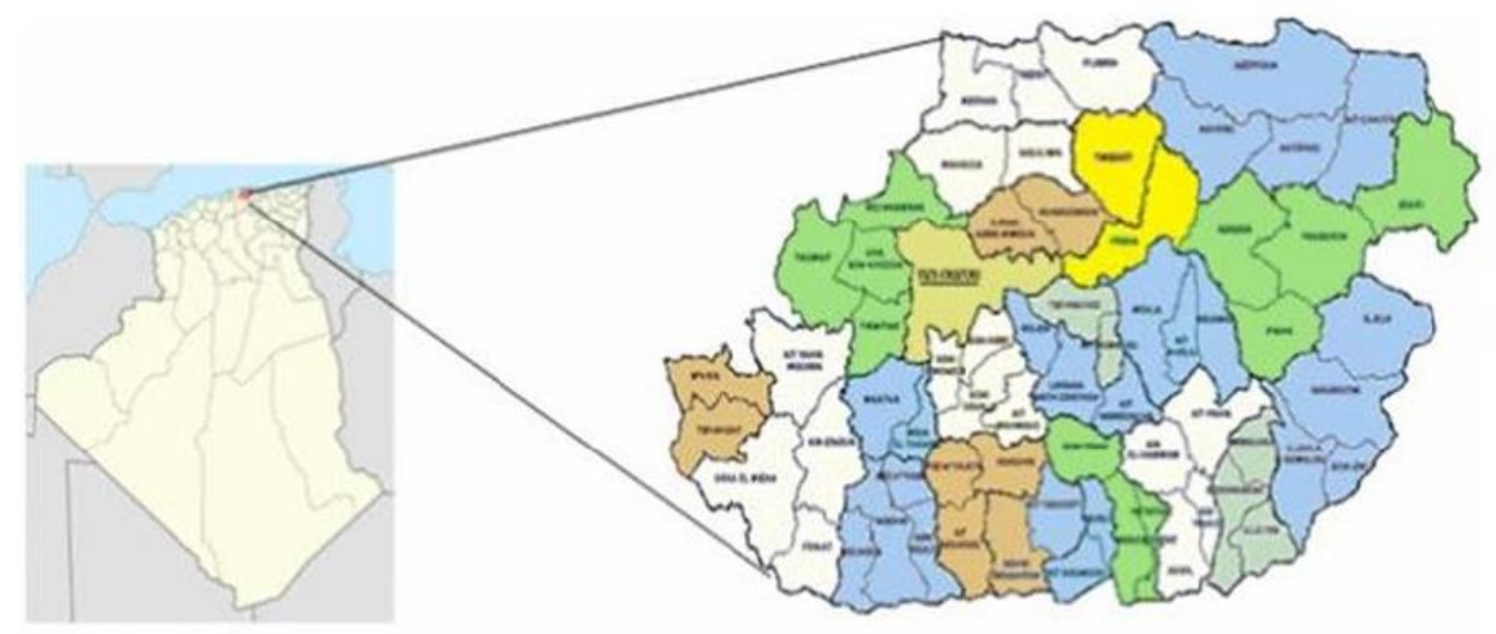

Figure 1. Study area department of Tizi-Ouzou commune of Freha

Source: A. Mouhous, Characterization of dairy cattle breeding in Algeria, 2015.

\section{Data and method}

\subsection{Methodological approach}

Following the studies (Mouhous, Djellal, Guermah, \& Kadi, 2020), (H.Sahraoui, T.Madani, \& F.Kermouche, 2016), (Saidani, Ziam, Hamiroune, Righi, \& Benakhla, 2019), we judged that the adapted approach for our study, will be to make a qualitative study, which is carried out near 30 stockbreeders in order to study the socioeconomic variables quoted in our review of literature. As well as a qualitative study, which is complementary, to detect the various brakes which meet the small stockbreeders on ground.

\subsection{Collection method}

Our data collection instruments are a questionnaire followed by an interview guide. The questionnaire was administered face-to-face and has five sections: Production and business activity, satisfaction, perceived value, recommendation intention, and breeder profile. The interview guide was administered to livestock professionals and included three themes: different marketing practices, organizational constraints faced by small-scale farmers and potential complementary resources to cow's milk.

\subsection{Questionnaire item}

Our questionnaire is composed of several sections:

- $\quad$ Respondent profile

- $\quad$ Eligibility

- $\quad$ Production and commercial activities

- Satisfaction

- $\quad$ Perceived value

- Intent to recommend. 


\subsection{Sampling}

Table 1. Sampling

\begin{tabular}{|l|l|}
\hline Study population & $\begin{array}{l}\text { Small dairy producers with an animal population between 1-5 } \\
\text { (cattle/goats) }\end{array}$ \\
\hline Sample size & 30 breeders, and 6 professionals \\
\hline Sampling method & Snowball effect \\
\hline Collection tools & Questionnaire and interview guide \\
\hline Method of administration & Face to face \\
\hline Survey period & $16 / 06 / 2021$ to 26/06/2021 \\
\hline Study area & Mountainous regions Freha wilaya of Tizi-ouzou \\
\hline Processing tools & SPSS, XLSTAT, Excel \\
\hline
\end{tabular}

Source: Author's own work.

\section{Results and discussion}

\subsection{Quantitative results}

According to the table below, we notice that our sample is composed of 18 men who represent $60 \%$ of our sample and 12 women who represent $40 \%$ of our sample. The results show that even women have an important role and contribute to the livestock activity. The age of the majority of the farmers varies between 45 and 54 years old, representing $53 \%$.

Description of the sample

Table 2. Profile of respondents

\begin{tabular}{|c|c|c|c|}
\hline Variables & Features & Workforce & Percentage \\
\hline Type & Male & 18 & $60 \%$ \\
& Woman & 12 & $40 \%$ \\
\hline Age & 35a 44years45a 54 years & 5 & $16 \%$ \\
& 55 years and older & 16 & $53 \%$ \\
& & 9 & $30 \%$ \\
\hline
\end{tabular}

Source: Own processing with SPSS.

\subsection{Descriptive analysis}

Table 3. Typical farm frequencies

\begin{tabular}{|c|c|c|}
\hline Variables & Frequency & Percentage \\
\hline Animal exploitation & 30 & $53,6 \%$ \\
\hline Plant exploitation & 28 & $46,4 \%$ \\
\hline
\end{tabular}

Source: Own processing with SPSS.

The results show that the majority of farmers have both animal and crop operations. It can be seen that farmers prefer to have mixed farms to cover the costs of feeding their animals. The results show that $46 \%$ of the farmers have a crop farm, $54 \%$ of them have an animal farm, and only $8 \%$ of the farmers do not have a mixed farm.

The results show also that $43 \%$ of the farmers own goats, and $57 \%$ of them own cows. It can be seen that cow milk is more important than goat milk in terms of profitability and production in the Tizi-ouzou area. The majority of producers process the milk produced by hand, with a percentage of $87 \%$, with only $13 \%$ of them not processing. It can be seen that small-scale farmers are much more interested in artisanal milk processing than in direct sales.

The result obtained showed that our respondents process milk into cheese with a percentage of $26.5 \%$, butter and the whey with a percentage of $25 \%$ each, and the curdled milk with $23.5 \%$. It can be seen that small-scale farmers prefer to make cheese than other by-products.

From the results obtained, we see that most of the smallholders market their dairy products and other processing 
with a percentage of $87 \%$, and only $13 \%$ who do not sell. It can be deduced that small producers are important actors, who also contribute to the growth of sales of dairy products.

To whom do you sell your milk or other processed products?

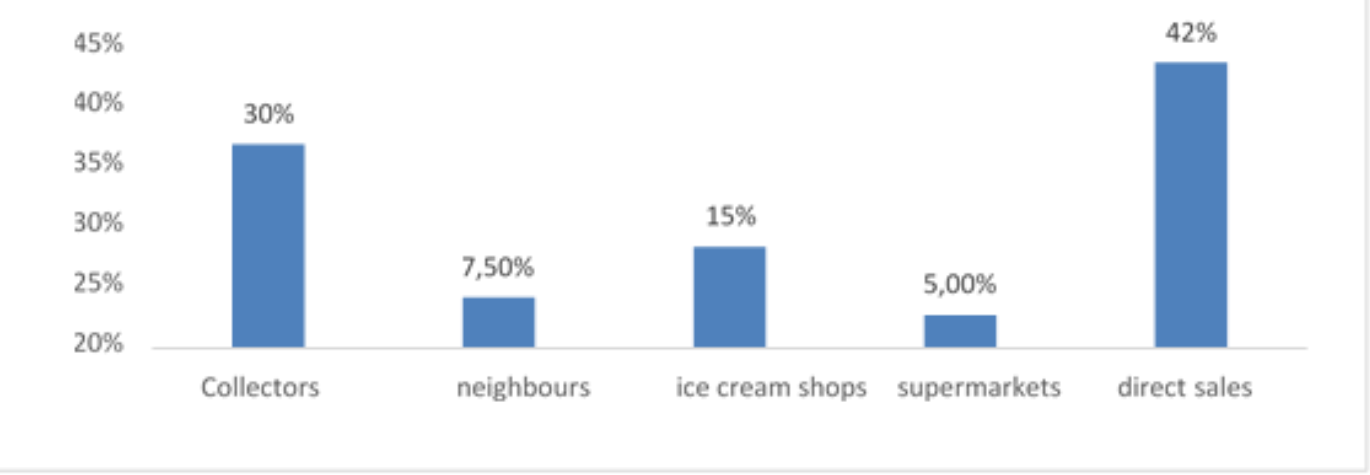

Source: Own processing with SPSS.

\section{Figure 2. Sales frequencies}

According to our results, we note that the majority of our respondents sell directly with a percentage of $42 \%$, while $30 \%$ sell their products to collectors. We can see that small producers prefer to have more freedom by selling their products directly, than to sell their milk to collectors at fixed prices.

The results show that $64 \%$ of the small-scale farmers are paid in cash, while $36 \%$ of them are paid on time. It can be deduced that $64 \%$ of the respondents prefer to be paid in cash, so it can be seen that they are engaged in direct selling.

Why you do not sell your processed products?

More than half of our respondents say that they do not sell their processed products because they work only with collectors with a percentage of $52 \%$, a percentage of $17.40 \%$ varied between lack of communication and "people are not ready for consumption". It is deduced that small producers cannot sell milk to collectors and process it at the same time.

Most of our respondents say they are "not at all satisfied" for profitability with a percentage of 33.30\%, 23.30\% say they are "somewhat satisfied" and a smaller part say they are "moderately and slightly satisfied". With a percentage of $20 \%$.

These results show that there are factors that negatively impact the profitability of smallholder production.

Table 4. Frequency of satisfaction with production operating conditions

\begin{tabular}{|c|c|c|c|c|c|}
\hline & Strongly disagree & Disagree & Neutral & Agree & Strongly agree \\
\hline Hygiene & $0,00 \%$ & $13,30 \%$ & $0 \%$ & $80,00 \%$ & $6,70 \%$ \\
\hline Conservation & $3,30 \%$ & $10 \%$ & $3,30 \%$ & \begin{tabular}{l|l}
$80 \%$ \\
\end{tabular} & $3,30 \%$ \\
\hline Sterilization & 0 & $20 \%$ & $10 \%$ & $63,30 \%$ & $6,70 \%$ \\
\hline Milking & $0,00 \%$ & $27 \%$ & $10,00 \%$ & $56,70 \%$ & $6,70 \%$ \\
\hline
\end{tabular}

Source: Own processing with SPSS.

According to the results obtained (Table $\left.{ }^{\circ} 4\right)$, the majority of the farmers say they "agree" on the hygiene and conservation conditions with a percentage of $80 \%$, only $63 \%$ "agree" on sterilization, and $56.70 \%$ "agree" on milking. It can be seen that the conditions of the small producers' farms are quite favourable for carrying out their activities. 


\section{What are your challenges?}

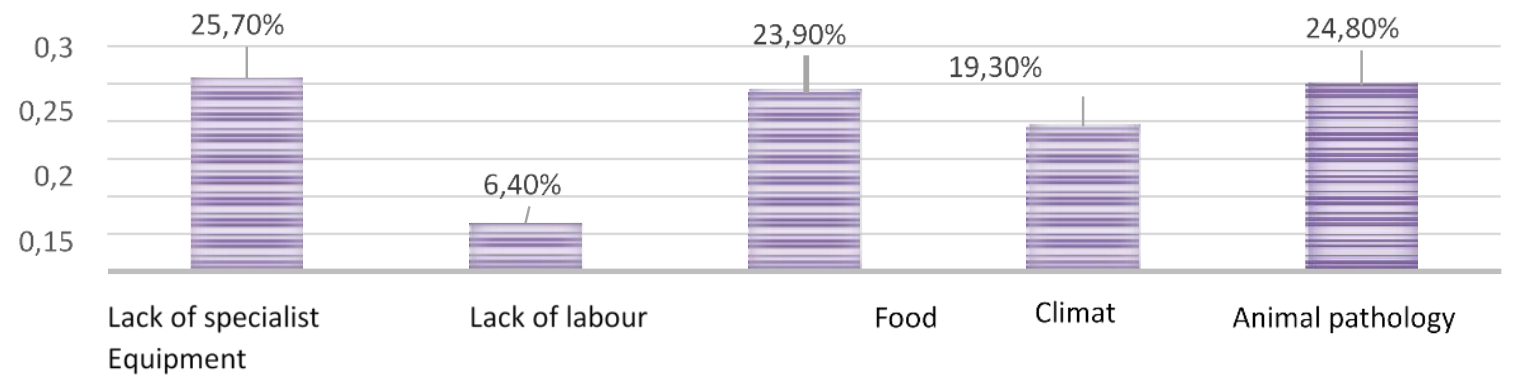

Source: Own processing with SPSS.

\section{Figure 3. Frequency of difficulties}

The graph shows that small-scale milk producers face several challenges in their production, with the percentage of lack of specialized equipment at $25 \%$, feed at $23.90 \%$, animal diseases at $24.80 \%$, and climate at $19.30 \%$.

With $50 \%$ of the respondents find that their product is good compared to other breeders in the region, $40 \%$ say their products are "very good", and only $10 \%$ find that their products are "excellent". We can see that the small breeders make quality products and have a competitive spirit.

On a scale of 1 to 5, do you think the quality of your products meets the expectations of your potential customers?

Table 5. Quality frequencies

\begin{tabular}{|l|l|l|l|}
\hline & Neutral & Agree & Strongly agree \\
\hline Results & $16,70 \%$ & $70 \%$ & $13,30 \%$ \\
\hline
\end{tabular}

Source: Own processing with SPSS.

The majority of small producers "agree" on the quality of their products with a percentage of $70 \%, 16.70 \%$ are "neutral", and only $13 \%$ of respondents are "very agree".

On a scale of 1 to 5 , do you think the quality of your products justifies their price?

With $50 \%$ of respondents are neutral, while $40 \%$ "agree", and only $10 \%$ of respondents "strongly agree". It can be seen that small producers who sell directly are convinced that their product deserves the price set.

Do you intend to expand your business in the future?

Table 6. Frequency of intent to expand activity

\begin{tabular}{|l|c|c|c|c|c|}
\hline & Definitely not & Probably not & Don't know & Probably & Definitely \\
\hline Results & $6,70 \%$ & $6,70 \%$ & $20 \%$ & $36,70 \%$ & $30 \%$ \\
\hline
\end{tabular}

Source: Own processing with SPSS.

The table $\mathrm{n}^{\circ} 6$ shows that $36.70 \%$ of the farmers plan to expand their farms, and $30 \%$ of them are certain to do so. We can deduce that there is a significant development perspective in the livestock activity. The results also shows that the majority of small producers have an average level with a percentage of $53 \%$, only $17 \%$ of our sample have a higher level. 


\subsection{Principal Correspondence Analysis PCA}

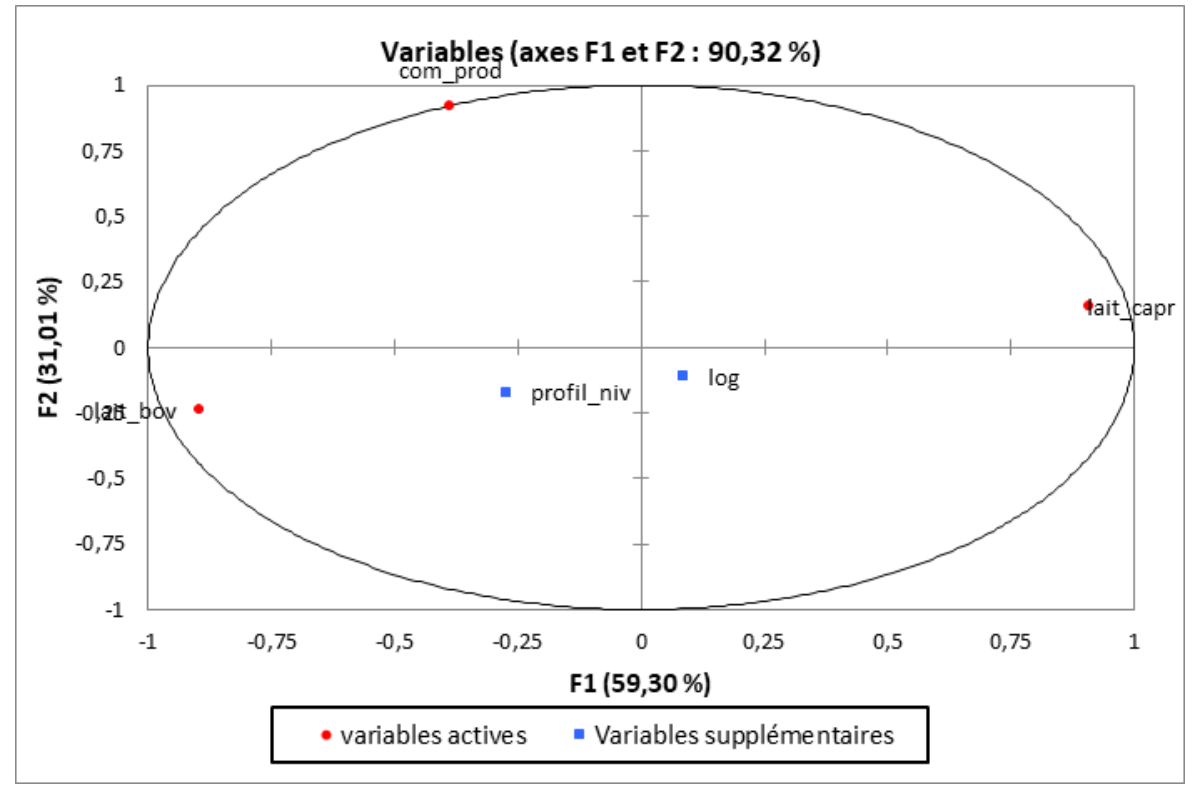

Source: XLSTAT.

Figure 5. Marketing variables and type of animals on the farm

The graph allows us to note that the variables indicated are very weakly correlated. It can be seen that the marketing of dairy products and the animal breed have a negative relationship.

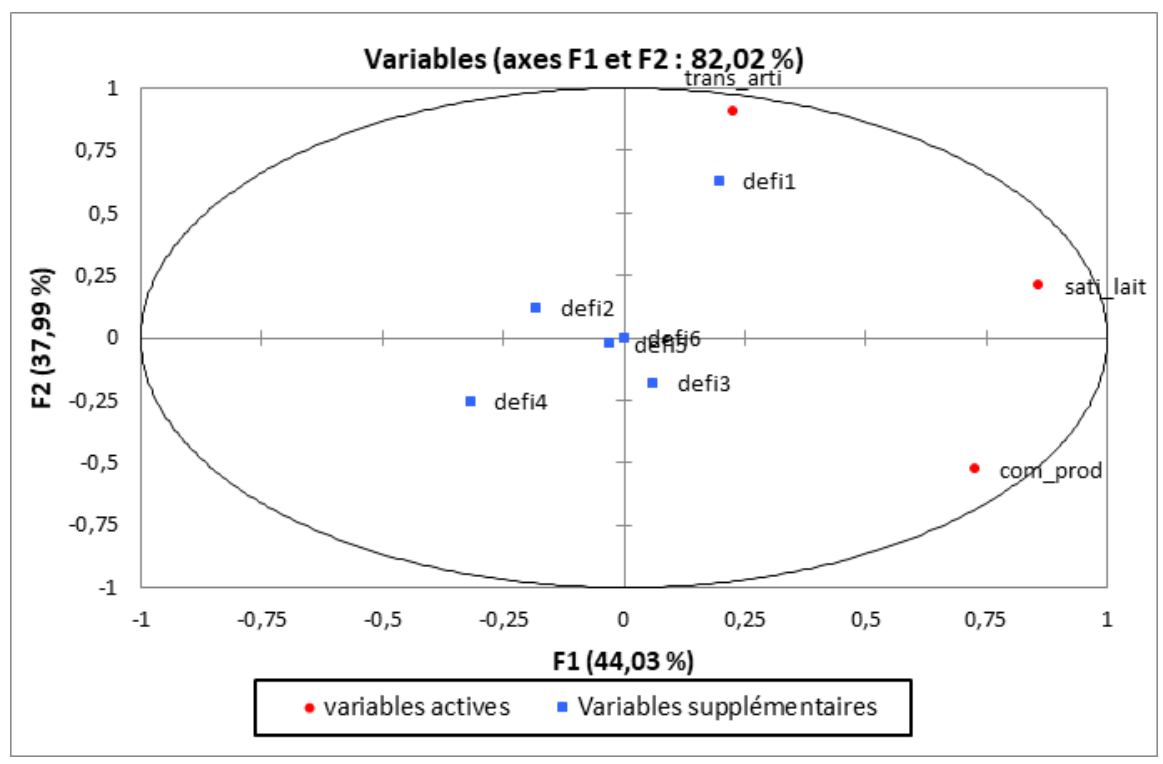

Source: XLSTAT.

Figure 6. Variables satisfaction, artisanal transformation and marketing of the product

Following the results of the graph. The variables are moderately correlated; there is a weak relationship between the satisfaction of milk, marketing of the product and artisanal processing. 


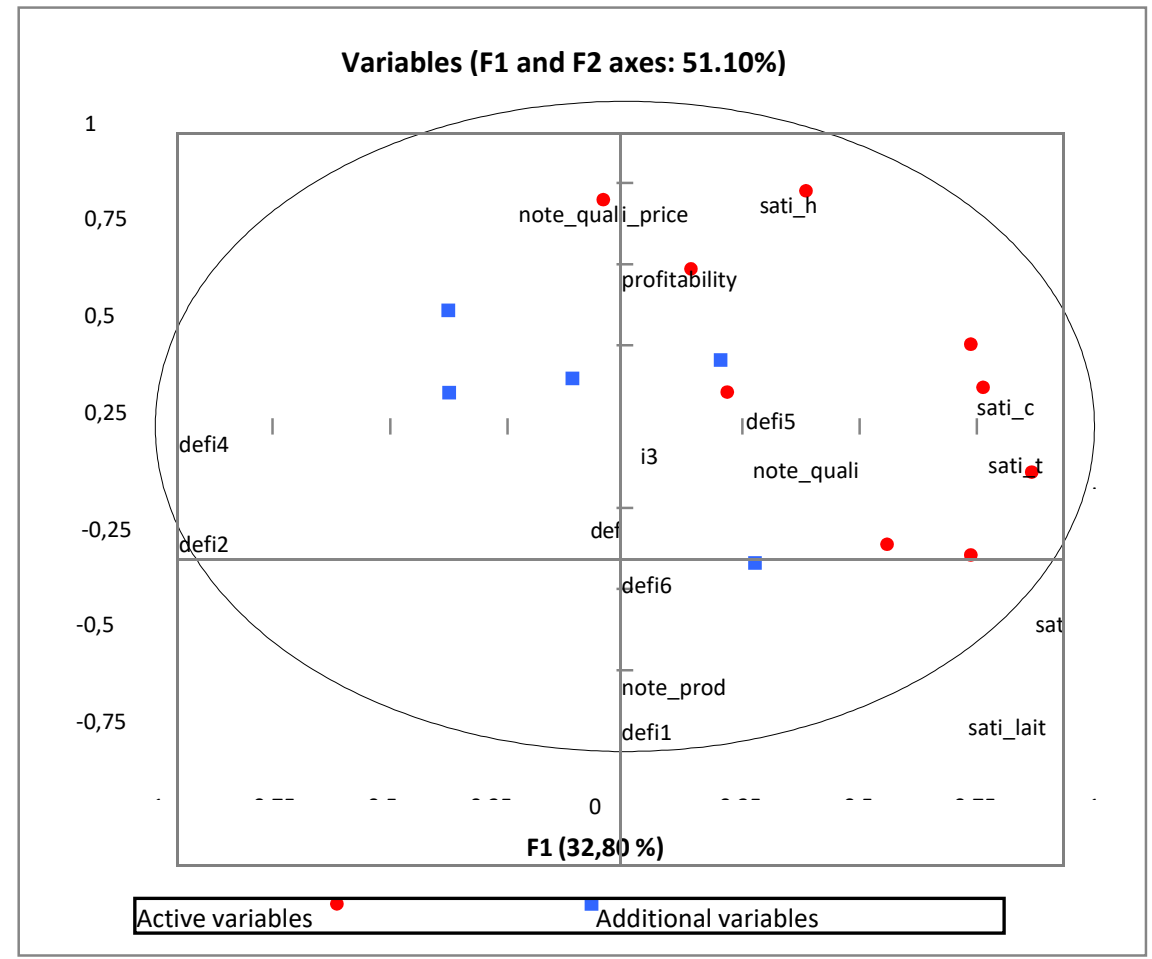

Source: XLSTAT.

Figure 7. Variables satisfaction, production profitability, product quality

The graph shows that there is a positive relationship between the degree of satisfaction with hygiene conditions, production profitability and product quality. It is also noted that there is a strong correlation between the rating of the products and the degree of satisfaction with the milk produced.

\subsection{Cross-tabulations}

The table 7 shows us that there is a significant relationship between bovine milk and collectors. It can be seen that collectors prefer to collect bovine milk. The results of the table show that goat milk producers do not sell their products to collectors.

The table shows that goat milk producers prefer to sell their product through direct channels.

Table 7. Profitability/Feeding variables

\begin{tabular}{|l|c|c|c|c|c|c|c|}
\hline \multicolumn{2}{|c|}{} & \multicolumn{5}{|c|}{ Production profitability } & \multicolumn{2}{c|}{\begin{tabular}{c} 
Total \\
\cline { 3 - 8 }
\end{tabular}} & Not at allsatisfied & $\begin{array}{c}\text { Not very } \\
\text { satisfied }\end{array}$ & $\begin{array}{c}\text { Somewhat } \\
\text { satisfied } \\
\text { satisfied }\end{array}$ & $\begin{array}{c}\text { Satisfied } \\
\text { Power } \\
\text { supply }\end{array}$ & Yes & 9 & 6 & 4 & 1 & 1 & 26 \\
\hline & No & 1 & 0 & 2 & 7 & 0 & 1 \\
\hline Total & & 10 & 6 & 6 & 7 & 30 \\
\hline
\end{tabular}

Source: Own processing with SPSS

It is found that there is a significant influence between the degree of satisfaction of the producer's profitability and the feeding of the animals on the farm.

The majority of respondents are "not at all satisfied" with the profitability of their production, and are impacted by food disruptions. 
Table 8. Profitability/level of education variables

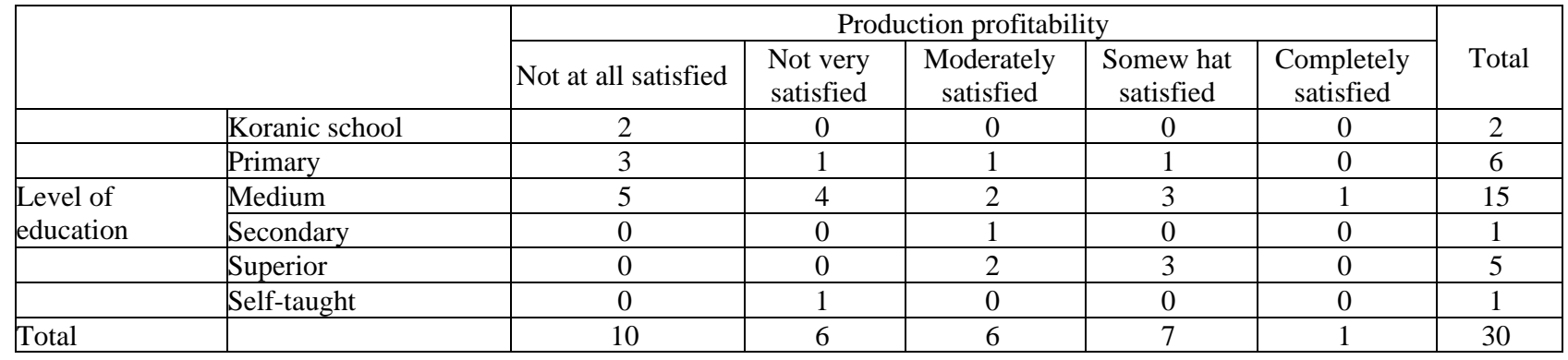

Source: Own processing with SPSS

From the results of the table, it can be seen that most of the respondents who have a lower than average level of education are "not at all satisfied" with the profitability of their production.

\subsection{Qualitative study}

\subsubsection{Marketing practices}

Question: Tell me about the different marketing practices that farmers adopt?

Table 9. Verbatim Marketing Practices

\begin{tabular}{|l|l|l|}
\hline \multicolumn{1}{|c|}{ Initials } & \multicolumn{1}{|c|}{ Position } & \multicolumn{1}{c|}{ Verbatimes } \\
\hline M.D & $\begin{array}{l}\text { Farmer and milk producer } \\
\text { Intensive cattle farm }\end{array}$ & $\begin{array}{l}\text { Cattle milk } \\
\text { Informal circuit: price volatility, direct sales } \\
\text { Formal channel: Fixed price,sale to collectors }\end{array}$ \\
\hline M.N & Dr. veterinarian, dairyfarmer & $\begin{array}{l}\text { Different marketing channels,poor organization } \\
\text { of the sector, difficulties in accessing the market }\end{array}$ \\
\hline M.A. & & $\begin{array}{l}\text { Cattle milk } \\
\text { Sale only to collectors, fixedprice. } \\
\text { Other sales channels, prices vary according to } \\
\text { the breeder. }\end{array}$ \\
\hline M.O & Milk collector (Soummam) & $\begin{array}{l}\text { Goat milk } \\
\text { Collectors are not interestedin goat's milk }\end{array}$ \\
\hline G.A & Cattle and goat farmer & $\begin{array}{l}\text { Poor organization, anarchic trade, different } \\
\text { circuitsbecause of subsidies }\end{array}$ \\
\hline
\end{tabular}

Source: Author's own work.

There are two types of marketing channels in Algeria, the informal channel and the formal channel. The poor organization of the dairy sector affects the marketing practices of milk producers. It can be seen that farmers prefer to set their own prices and market their products through informal channels. The low production of goat milk does not interest collectors, which explains why goat milk producers use informal channels for marketing practices.

\subsubsection{The brakes on production}

Question: What is the obstacles of breeders?

Table 10. Verbatim obstacles encountered

\begin{tabular}{|c|l|l|}
\hline Initials & \multicolumn{1}{|c|}{ Position } & \multicolumn{1}{c|}{ Verbatimes } \\
\hline M.D & $\begin{array}{l}\text { Farmer and milk producer } \\
\text { Intensive cattle operation }\end{array}$ & $\begin{array}{l}\text { Food prices, climate, bad practices, } \\
\text { marketing of products, financial means of } \\
\text { the breeder, diseases }\end{array}$ \\
\hline M.N & Dr. veterinarian, dairyfarmer & $\begin{array}{l}\text { The market, Rough terrain,food, prices, } \\
\text { distribution, cultural factors }\end{array}$ \\
\hline
\end{tabular}


Table 10 (cont.). Verbatim obstacles encountered

\begin{tabular}{|c|l|l|}
\hline Initials & \multicolumn{1}{|c|}{ Position } & \multicolumn{1}{c|}{ Verbatimes } \\
\hline M.A. & Milk collector (Soummam) & $\begin{array}{l}\text { Covid-19, Prices, Feed, climate, milk } \\
\text { quality, diseases, lack of means, hygiene, } \\
\text { poor husbandry practices }\end{array}$ \\
\hline M.O & Cattle and goat farmer & $\begin{array}{l}\text { Lack of space, Food, climate,Price, } \\
\text { distribution, covid 19, marketing, Quality }\end{array}$ \\
\hline G.A & Farmer and small livestockproducer & $\begin{array}{l}\text { Breeds, prices, climate, pathologies, lack of } \\
\text { means, cultural factors, hygiene }\end{array}$ \\
\hline
\end{tabular}

Source: Author's own work.

Respondents testify that there are many factors that impact the dairy sector in Algeria. According to M.D.'s testimony, the price of livestock feed has not stopped increasing since 2016 to date. The Covid-19 which has negatively impacted the distribution and collection of milk, the climatic factor, Algeria has experienced several periods of drought that were not favorable to production. Some producers found themselves having to pay for water supplies.

The socio-cultural factor that prevents the use of private land for natural animal feeding. The lack of means of the stockbreeders which has a negative impact on the production conditions, as well as the level of education.

\subsubsection{The resources of the dairy basin}

Question: Algeria has several other resources such as goat milk and sheep milk, why do you think they are not exploited?

Table 11. Dairy pool resources

\begin{tabular}{|l|l|l|}
\hline \multicolumn{1}{|c|}{ Initials } & \multicolumn{1}{|c|}{ Position } & \multicolumn{1}{|c|}{ Verbatimes } \\
\hline M.D & $\begin{array}{l}\text { Farmer and milk producer Intensive } \\
\text { cattle operation }\end{array}$ & $\begin{array}{l}\text { Difficulty in selling goat's milk, genetic } \\
\text { problem, lack of research, raw milk easily } \\
\text { perishable, more expensive processing, }\end{array}$ \\
\hline M.N & Dr. veterinarian, dairy farmer & $\begin{array}{l}\text { Low profitability for farmers, no } \\
\text { collections, lack of dairy breeds }\end{array}$ \\
\hline M.A. & Milk collector (Soummam) & $\begin{array}{l}\text { We do not collect goat milk, not known in } \\
\text { our region, low production, low } \\
\text { profitability, not interesting }\end{array}$ \\
\hline M.O & Cattle and goat farmer & $\begin{array}{l}\text { The cow produces better, low production, } \\
\text { more expensive milk, price of materials, }\end{array}$ \\
\hline G.A & Farmer and small livestock producer & $\begin{array}{l}\text { Poor organization of the sector, lack of } \\
\text { dairy breeds, lack of professionalism }\end{array}$ \\
\hline
\end{tabular}

Source: Author's own work.

According to the results obtained, it can be seen that other resources that are complementary to bovine milk production are neglected and poorly organized. The production of goat milk does not interest farmers because of the low profitability of production, as well as the scarcity of collectors of goat milk. The characteristics of goat milk, raw milk easily perishable, and the processed products from goat milk have quite high prices, which probably impact the intention of purchase of consumers, and explains the difficulty of its marketing. The lack of communication about its resources has a negative effect on the consumer culture, as people are not used to consuming a product derived from sheep or goat milk. The genetics of the breeds of goats and sheep that exist in Algeria have a low milk production; the lack of professionalism in this sector has consequences, which can influence the growth of the dairy basin. According to Mr. N.B., "as far as sheep milk is concerned, it is feasible to breed a male that is compatible with the female breed of Oued Djelal, in order to obtain a milk-producing breed, an experiment that has been successful in Jordan.

For goat farms, it is better to make nurseries of Spanish Murcia goat, the best is to think of making industrial 
farms more important to be able to supply the goat milk, which is more important than the cow milk.

\section{Discussion}

\subsection{Socio-economic situation of small-scale livestock farmers}

The results of our research show that the activity of the breeding in the region of Tizi-Ouzou is practiced by the women and the men with a percentage of $60 \%$ which represents the male gente, and $40 \%$ represents the female genre. These results are similar to the study of (S.A.KADI and al, 2014) which shows that the activity of the breeding is a male activity with a percentage of $86,2 \%$ which represents the men.

The average age of the breeders varies between 45 and 54 years, which represents $53 \%$ of the sample studied. According to the study of (k.Dieng, 2014), the average age of the 242 actors in his sample is 44 years. While the results of (S.A.KADI, 2013) show that, the average age varies between 30-60 years with a percentage of $73 \%$. (Mouhous, Djellal, Guermah, \& Kadi, 2020) the average age of the farmers is 35 years. It can be seen that the results of our research are close to the work of other researchers in the dairy sector.(Mouhous, Djellal, Guermah, \& Kadi, 2020) Its results prove that livestock activity is practiced much more by adults, and neglected by young people.

As for the level of education of the farmers, our study shows that the majority of the small producers have an average level with a percentage of 53\%; only $17 \%$ of our sample have a higher level. Comparing our results with the results of the study of (k.Dieng, 2014) only $0.8 \%$ have a higher level. According to (S.A.KADI, 2013) the level of education among the herders is often low, with a percentage of $32 \%$ who have an average level and only one herder who has higher education. The results show that all the respondents' main activity is cattle farming. Less than 5\% have a secondary activity. We can validate our hypothesis H2 "The socio-economic status of small- scale dairy farmers has a direct relationship with the productivity and profitability of the farmers".

\subsection{Business practices}

According to the results of our study, the milk sector in Algeria comprises two marketing channels, the formal and the informal, unlike the dairy sector in Switzerland, which comprises three main sales channels: industrial products, cheeses and other dairy specialties. (Sophie Reviron, 2018). According to our results, farmers prefer to set the price themselves by selling their milk production directly with a percentage of $42 \%$. According to the study by (Hochuli, Hochuli, \& Schmid, 2021) Farmers are engaging in direct marketing, for a better income. Consumers are looking for security of supply and traceability of products.

According to the authors, the goat milk sector in the wilaya of Tizi-Ouzou remains less structured. The collectors target the farms with easy access and approved. Our qualitative study shows that collectors are not interested in goat milk because of its low profitability. This explains the poor organization of commercial practices of the actors of the dairy basin in the region of Tizi-Ouzou. 50\% of the respondents find that their product is good compared to other breeders in the region, $40 \%$ say that my products are "very good", our study shows that small breeders make quality products and have a competitive spirit. According to (Sophie Reviron, 2018) the originality and quality of the ingredient is a key element in determining its value. We can therefore validate our hypothesis H1 "The lack of goat milk collectors negatively impacts the milk production ier of goat flocks."

\subsection{Organizational barriers}

In the majority of the farms visited, small-scale milk producers face several challenges during production, we found quite high percentages regarding the lack of specialized equipment with a rate of $25 \%$, feed at $23.90 \%$, animal diseases at $24.80 \%$, and finally the climate with a percentage of $19.30 \%$. The results of our study are close to the different researches established in the literature review. According to (J.P., 2016) In this study, we found that food is a key factor influencing the strategies of producers and agricultural enterprises, (Lazereg, Bellil, Djediane, \& Zaidi, 2020) the food is a key factor that influences the strategies of producers and agricultural enterprises. The dairy production in Algeria knows several structural flaws, which prevent the 
normal development of the production process; the climatic conditions form a limiting factor of the evolution of this sector, especially the cheese production that constitutes the main obstacle.

According to (J.P., 2016) Food plays an important role in the production and variation of the quality of milk (Kebaili, 2021). 17.40\% of our respondents say that they do not have communication around their products, which has a strong impact on milk production and marketing. According to (Barragan-ochoa, 2018) the factors that impact the normal course of the marketing process are the distribution of perishable dairy products to the consumers, as well as the poor means of communication.

The geographical location of the dairy sectors is an important element in the strategic orientation towards specialization or diversification. We can therefore confirm our hypothesis H3 "The poor management of actors, the lack of instruction and professionalism negatively impact the production of small-scale farmers.

\section{Conclusion}

Our study aimed at finding out the organizational constraints faced by smallholder farmers, and identifying their different marketing practices. The results of our study confirm that the majority of cattle farmers sell their products to collectors, unlike small-scale goat farmers who favour direct sales due to the lack of goat milk collectors who consider it unprofitable for them. On the other hand, we found through interviews with professionals, that there are flaws, and brakes that impact negatively on dairy production and marketing. It was found that most farmers are not satisfied with their profitability; due to several factors including the price of feed which has been increasing since 2016, climate changes that negatively impact the farms. Several cow and goat farmers spend on water supply for their livestock, as well as socio-economic and cultural factors, including the level of education that influences the breeding practices, according to M.D "those who have inherited this knowledge do not apply breeding practices according to the standards".

The instability of this sector and the lack of income for farmers lead them to engage in other activities, which results in a lack of professionalism and innovation in this area. The impact of covid-19 has caused changes in the distribution of milk and feed, which has led to an increase in prices, while at the same time the price of milk has not changed. Following our results, we can say that our two hypotheses formulated at the beginning of our work are confirmed. We encountered limitations during our field study, such as the inaccessibility of smallscale farmers in the mountainous regions of Freha. The constraint of the Kabyle language, which poses a communication barrier between the interviewer and the respondents. Some did not want to answer the questionnaire because of their confidential marketing practices.

Finally, we suggest that small breeders follow training courses on breeding methods and good practices, and improve hygiene and sterilization conditions on the farms, and strengthen the health control systems at the farm level. The contribution of the Algerian state for the regularization of the prices of animal products. To practice a good communication around the products processed by the small breeders to increase the marketing and sensitize the consumers to consume natural products. Exploit various other resources such as sheep milk by improving the dairy breeds of Ouled Djellal. Orient goat farms towards intensive operations, and promote dairy breeds such as the Spanish Murciana and the French Saanen.

Funding: self-funded.

Author contribution: conceptualization, Lyna Mokhtari, Mehdi Bouchetara, Messaoud Lazreg; data curation, Lyna Mokhtari, Mehdi Bouchetara, Messaoud Lazreg; formal analysis, Mehdi Bouchetara, Lyna Mokhtari, Messaoud Lazreg; funding acquisition, Lyna Mokhtari, Mehdi Bouchetara; investigation, Lyna Mokhtari, Mehdi Bouchetara; methodology, Mehdi Bouchetara, Messaoud Lazreg, Lyna Mokhtari; software, Messaoud Zerouti; supervision, Mehdi Bouchetara, Messaoud Lazreg; validation, Sabrina Iraten, Lamia Elmokretar, Messaoud Lazreg, Mehdi Bouchetara; visualization, Mehdi Bouchetara; writing - original draft, Mehdi Bouchetara, Lyna Mokhtari, Messaoud Lazreg; writing - review \& editing, Mehdi Bouchetara, Messaoud Lazreg, Lyna Mokhtari. 


\section{References}

1. Azeddine, M., Ammar, K. S., \& Fatima, B. (2015). Adaptation strategies of goat breeders in the mongtagnous zone of Tizi-Ouzou. European Scientific Journal, 11(2). [Link].

2. Barragan-ochoa, F. (2017). Small producers, cities and milk: Challenges of food provisioning in the northern Andean. Université Paris 1 Panthéon Sorbonne, [Link].

3. Dieng, K., Kalandi, M., Sow, A., Millogo, V., Ouedraogo, G.A. And Sawadogo, G.J. (2014). Socioeconomic profile of the actors of the local milk value chain in Kaolack Senegal. Revue Africaine de santè et de productions animales, 12(03-4). [Link].

4. Farid Djellal, Azeddine Mouhous, Si Ammar Kadi. (2018). Performance of rabbit farming in the TiziOuzou region. Hal, 8. [Link].

5. Hochuli, A., Hochuli, J., \& Schmid, D. (2021). Competitiveness of diversification strategies in agrigultural dairy farms: Empirical findings for rural regions in Switzerland. Journal of Rural Studies, 82, 98-106. [Link].

6. Kadi S.A., Hassini F., Lounas N., Mouhous A. (2014). Characterization of goat breeding in the mountainous region of Kabylia in Algeria. Options Méditerranéennes : Série A. Séminaires Méditerranéens; n. 108. [Link].

7. Lazereg, M., Bellil, K., Djediane, M., \& Zaidi, Z. (2020). The Algerian milk sector facing the consequences of the covid-19 pandemic. Les cahier du cread, 36, 234-246. [Link].

8. Ludovic Temple, Frederic Lançon, Florence Palpacuer, Gilles Paché. (2013). Updating the commodity chain concept in agriculture and agribusiness. Economies et Sociétés. Série AG Systèmes agroalimentaires, Presses del'ISMEA, AG(33), 1785-1797. [Link].

9. Makhlouf, M., Montaigne, E., \& Tessa, A. (2020). Dairy policy in Algeria: between food security and differential consumption support. New Meditin, New medit: Mediterranean journal of economics, agriculture and environment, 14, 12-23. [Link].

10. Martine Napoleone, Jean-Pierre Boutonnet. (2016). Reconfigurations of agri-food systems in territories and value chains. FAO-CIHEAM Network for Research and Development in Sheep and Goats. [Link].

11. Missouhou, A. (2020). The value chain of milk and dairy products: Situation in front of covid-19 and strategies of the actors in senegal. Initiative Prospective Agricole et Rurale, 10-19. [Link].

12. Mouhous, A., Djellal, F., Guermah, H., \& Kadi, S. A. (2020). Technical and econonic performance of dairy cattele farming in mountain areas in tizi-ouzou, Algeria. Biotechnology in Animal Husbandry. [CrossRef].

13. Reviron, S. and Python, P. (2018). Value distribution analysis in the dairy sector. Swiss Agricultural Research, 9(4). [Link].

14. Sahraoui H., Madani T., Kermouche F. (2016). the development of a goat milk sector in mountain regions: an asset for sustainable regional development in Algeria. Pp. 677-681. [Link].

15. Saidani K., Ziam H., Hamiroune M., Righi S., Benakhla A., (2019). Small ruminant rearing in Kabylia, Algeria, and prospects for its development. Rev. Elev. Med. Vet. Pays Trop., 72(2), 49-54, [CrossRef].

16. Si Ammar Kadi, Azeddine Mouhous, M. Berchiche, Farid Djellal, J. Huguenin, et al. (2018). Production performance and marketing of milk in goat farms in the mountainous area of Tizi-Ouzou. Hal, 7. [Link].

17. Si-Tayeb H, Mouhous A et Cherfaoui L M. (2015). Characterization of dairy cattle breeding in Algeria: case of the Freha Tizi-Ouzou area. Livestock Research for Rural Development, Volume 27, Article \#128. [Link].

18. Soltani, M. Z. (2017). Reasoning in terms of value chains: Approaches and limitations. Revue Économie, Gestion et société. [Link].

19. Srairi, M. T., Bahri, S., \& Kuper, M. (2013). Work and its contribution to the adaptation strategies of smallholder family farms within mixed crop/livestock systems in Morocco. Biotechnol. Agron. Soc. Environ., 17(3). [Link].

20. Yilmaz-Ersan, L., Ozcan, T., \& Akpinar-Bayizit, A. (2020). Assessment of socio- demograpgic factors, health status and the knowledge on probioptioc dairy products. Food Science and Humain Wellness, 9(3). [CrossRef].

21. Khelaf Saidani (2021). Goats in Algeria: breeding, production and inventory. [Link]. Consulted 02/07/2021. 